\title{
Decoupling of copepod grazing rates, fecundity and egg-hatching success on mixed and alternating diatom and dinoflagellate diets
}

\author{
Jefferson T. Turner ${ }^{1, *}$, Adrianna Ianora ${ }^{2}$, Antonio Miralto ${ }^{2}$, \\ Mohamed Laabir ${ }^{2, * *}$, Francesco Esposito ${ }^{2}$ \\ ${ }^{1}$ School for Marine Science and Technology, University of Massachusetts Dartmouth, 706 South Rodney French Boulevard, \\ New Bedford, Massachusetts 02744, USA \\ ${ }^{2}$ Stazione Zoologica 'A. Dohrn', Villa Comunale 80121 Naples, Italy
}

\begin{abstract}
Experiments were conducted over 10 to 20 d periods to study the grazing and reproductive success of the copepod Temora stylifera fed on unialgal cultures of the diatom Thalassiosira rotula (THA) or the dinoflagellate Prorocentrum minimum (PRO), as well as mixtures of THA and PRO (MIX experiments) and alternating diets of THA and PRO switched daily (SWITCH experiments). Adult females ate both THA and PRO, and while rates of feeding on the 2 diets were similar in terms of carbon ingestion, egg production was generally higher on the diatom diet. In contrast, copepod egg-hatching success was low on the diatom diet, declining rapidly after $2 \mathrm{~d}$ from $>80$ to $0 \%$ by Day 17. The diminution in hatching success was slower when females were fed MIX or SWITCH diets, but nonetheless diminished to 0 and $<25 \%$ by the end of the experiment, depending on the incubation method. Only in the case of the PRO diet was egg viability high and stable with time (87 to $96 \%$ ), regardless of whether female and male couples were incubated as individual couples in crystallizing dishes or as triplicate couples in rotating bottles. However, in most other cases, the incubation method (crystallizing dishes vs rotating bottles) had very strong effects on egg and fecal pellet production, and hatching success. Higher egg production rates were generally obtained when females were incubated in crystallizing dishes, whatever the diet, although fecal pellet production rates were significantly higher in the rotating bottle experiments in most cases. Egg-hatching success was also strongly affected by incubation method, with generally higher hatching rates in the rotating bottles. This was probably due to the fragility of non-viable eggs, which were more easily destroyed by mechanical disturbance in rotating bottle experiments. The results support the recent discovery that reproductive failure in copepods can be due to deleterious antimitotic compounds present in some diatoms that arrest normal embryonic division. Reduction in egg viability was not only visible when females were fed unialgal diatom diets, but also when they were fed mixed diets. However, on mixed diets there was a 'dilution effect' in that hatching was reduced by approximately half, and this took about twice as long to occur. The evolutionary advantages for diatoms in producing antimitotic compounds are discussed, as well as questions of why copepods feed on diatoms with impunity, even though some diatoms are detrimental to copepod reproductive success.
\end{abstract}

KEY WORDS: Copepod grazing $\cdot$ Egg production $\cdot$ Egg viability $\cdot$ Diatom $\cdot$ Temora stylifera $\cdot$ Gulf of Naples, Italy

Resale or republication not permitted without written consent of the publisher

\section{INTRODUCTION}

It has long been known that copepod egg-production rates are related to quantity and composition of mater-

\footnotetext{
*E-mail: jturner@umassd.edu

${ }^{* *}$ Present address: Université de Montpellier II, Place Eugene Bataillon, 34095 Montpellier, France
}

nal diets (Jónasdóttir et al. 1995, Ianora 1998 and references therein). However, recent studies have revealed that relations between food quantity and quality, and copepod egg-production and egg-hatching success are complex. Some diets that are good for egg production may not be good for egg viability and hatching. In particular, there is mounting laboratory evidence (summarized by Ianora 1998) that several species of diatoms, 
although good food for adult copepod survival and high production of eggs, contain embryogenic inhibitors that cause reduced hatching of eggs and abnormal naupliar development.

There is also field evidence suggestive of inhibition of copepod egg viability by diatom diets. In the English Channel, egg-hatching rates declined under seasonal or hydrographic conditions, promoting dominance of diatoms rather than non-diatoms (Laabir et al. 1995, 1998). In the Adriatic Sea, Miralto et al. (1999) recorded a strong diminution in copepod hatching success during the spring diatom bloom composed primarily of Skeletonema costatum and Pseudo-nitzschia delicatissima in 1997, and P. delicatissima in 1998. Although these blooms triggered increased egg-production rates by the copepod Acartia clausi, mean egg-hatching success during these blooms was only 12 and $24 \%$, respectively, compared to $90 \%$ during the summer when diatom concentrations were lower. Miralto et al. (1999) reported the presence of 3 low molecular weight aldehydes from the diatoms Thalassiosira rotula, S. costatum and P. delicatissima that had antimitotic properties not only for copepod eggs, but also for sea urchin embryos and human colon cancer cells. Miralto et al. suggested that these aldehydes are the probable agents of reproductive failure in copepods when diatoms are the major food source. Together, these observations imply that the classic view of the spring diatom bloom as an initiator of copepod reproduction and planktivorous fish recruitment in temperate waters (e.g. Cushing 1989, Legendre 1990 and references therein) is potentially much more complicated (Kleppel et al. 1991).

Despite the extensive body of evidence discussed above, the notion that diatom diets are deleterious to copepod reproductive success is not without its critics (Jónasdóttir et al. 1998). Adult copepods have been known to ingest diatoms since at least the studies of Dakin (1908) and Marshall (1924), and several species of copepods have been reared on diets that include diatoms (Paffenhöfer \& Harris 1979). Rates of copepod egg-production are often high on diets of natural phytoplankton that are dominated by diatoms (Irigoien et al. 2000). Thus, there is skepticism that diatoms might impair copepod reproduction. What may be unappreciated is that foods or environmental conditions that are good for copepodites and adults may not necessarily be as good for younger stages of the copepod life cycle such as nauplii or eggs. Further, foods that promote high copepod egg-production do not necessarily promote high egg-hatching success. If certain diatoms contain compounds that block embryogenesis in copepod eggs, these diatoms may be much more harmful to developing copepod eggs than to later stages such as copepodites and adults (Ianora et al. 1999a).
There have been several suggestions that variations in copepod egg viability and hatching success appear to be more related to inadequacy of specific nutritional factors rather than to antimitotic inhibitors in the diets of certain diatoms (see Jónasdóttir et al. 1998 and references therein). However, the role of various dietary components in egg-hatching success is not resolved. For instance, parameters such as egg size, levels of egg protein, carbohydrate and lipid content, fatty acids, or amino acids, exhibit differing relationships with egghatching success and naupliar survival (Jónasdóttir 1994, Guisande \& Harris 1995, Jónasdóttir \& Kiørboe 1996, Pond et al. 1996, Koski et al. 1998, 1999, Klein Breteler et al. 1999, Laabir et al. 1999). In fact, evidence supporting the 'nutritional deficiency' hypothesis is largely circumstantial and based primarily on the correlation between the biochemical content of the food and resulting copepod hatching success. There has not yet been rigorous experimental testing of the effects of a nutritional deficiency on the egg-hatching success of copepods.

Even if nutritional inadequacies in some copepod foods deter maximum efficiency of egg-hatching success, it may not particularly matter in nature, because most copepods are broadly omnivorous, ingesting a variety of diatom, dinoflagellate, other phytoplankton, heterotrophic protist, and micrometazoan food items (reviews by Marshall 1973, Turner 1984, 2000, Kleppel 1993, Turner \& Roff 1993, Mauchline 1998). Recent studies have revealed that some calanoid copepods previously regarded as 'herbivores' extensively ingest, and sustain fecundity upon, diets of heterotrophic protists such as oligotrich ciliates (Ohman \& Runge 1994), and that such copepod production can contribute to larval fish recruitment during periods of low phytoplankton chlorophyll (Runge \& de Lafontaine 1996). Thus, it seems that nutritional inadequacies in some copepod foods could be overcome by ingestion of others. Indeed, Schmidt \& Jónasdóttir (1997) found that mixed diets of diatoms and cyanobacteria supported higher copepod fecundity than unialgal diets.

Realization that some species of diatoms do not promote good copepod egg-hatching success should not assume that all diatoms are inhibitory. Indeed, Ianora et al. (1995) found that egg-production and hatching success varied between several unialgal diatom diets. In some cases, algal diets that promoted high egg-production did not promote high egg-hatching success. Highest rates of both egg production and egg hatching were obtained on diets of natural mixed phytoplankton/microzooplankton assemblages. However, in general, egg viability was not as high with any of the unialgal diatom diets as with unialgal nondiatom diets. This conclusion was supported by a 
multi-investigator study (Ban et al. 1997), which revealed that for 16 different copepod species all but one of 17 species of diatoms significantly reduced egg-production rates and/or egg viability compared to non-diatom controls.

It seems important to clarify whether copepod embryogenic inhibitors contained in diatoms are exudates, extracts, or 'ingestates'. As stated by Jónasdóttir et al. (1998), exudates are compounds that leak out of, or are exuded by phytoplankton cells, whereas extracts are solutes originally contained in phytoplankton cells that are liberated by artificial disruption such as centrifugation and sonication. Jónasdóttir et al. stated that exudates and extracts may contain different compounds, and that demonstration of deleterious effects on embryonic development and egg-hatching by such compounds is 'ecologically irrelevant' because the effects are 'evident only at concentrations that exceed those encountered in nature by many orders of magnitude'. We agree, but with an important caveat. Experiments with high concentrations of extracts, such as those presented by Poulet et al. (1994), Uye (1996), Lee et al. (1999), and Starr et al. (1999), and those testing purified aldehydes (Miralto et al. 1999), do reveal that embryogenic blockage is caused by chemicals. Of course, such chemicals are far too dilute in the sea to have such an effect on copepod eggs through direct exposure. However, if such chemicals become accumulated in female copepods through feeding on diatoms that contain them, then concentrations within the females could become high enough to have an antimitotic effect on developing eggs. In essence, such chemicals would be 'abortive' compounds with birth-control effects.

If copepod embryogenesis is inhibited by metabolites in Thalassiosira rotula and some other diatoms, it may be that egg viability is low even when egg-production and feeding rates on diatom diets are high. There may also be different effects in feeding, egg-production and egghatching experiments in which copepods are fed either mixed or alternating diets of the diatoms and nondiatoms. Thus, in addition to measuring fecundity and egg viability, the rates of feeding on the diatom and nondiatom diets should be quantified. Although Starr et al. (1999) found that the proportion of non-viable eggs produced by Calanus finmarchicus females increased with increasing rates of ingestion of the diatom Thalassiosira nordenskioldii, prior to our study there appears to have been no simultaneous comparisons of ingestion rates, egg-production rates and egg viability by copepods feeding upon diatom and non-diatom diets. Accordingly, in November of 1997, we performed such experiments with the copepod Temora stylifera from the Gulf of Naples feeding upon mixed and alternating diets of the diatom Thalassiosira rotula and the dinoflagellate Prorocentrum minimum.

\section{MATERIALS AND METHODS}

Grazing experiments. Three types of grazing experiments were performed: (1) grazing on unialgal cultures of Thalassiosira rotula (THA 30 to $40 \mu \mathrm{m}$ diameter, $157.62 \mathrm{pg} \mathrm{C}$ cell $^{-1}$ : Ianora \& Poulet 1993) or Prorocentrum minimum (PRO, 14 to $22 \mu \mathrm{m}$ length, 10 to $15 \mu \mathrm{m}$ width, $274.19 \mathrm{pg} \mathrm{C}$ cell $^{-1}$ : Ianora \& Poulet 1993) as single diets ('THA' and 'PRO' experiments); (2) grazing in which the 2 algae were provided in mixtures (hereafter referred to as 'MIX' experiments); or (3) grazing whereby copepods were switched from diets of THA to PRO, and vice versa every day (hereafter referred to as 'SWITCH' experiments). This was done to ensure that females would ingest both cell types in one way or the other.

In all cases, copepods were adult females of Temora stylifera, collected from the Gulf of Naples at the beginning of each experiment and transferred from treatment to treatment throughout each experiment. In anticipation of replacing copepods that might die during experiments, numerous alternate copepods were kept in reserve, and exposed to the same conditions as experimental inviduals, including daily switching to different food suspensions.

Experimental procedures were similar for all grazing experiments. Five copepods were added to each of triplicate $500 \mathrm{ml}$ experimental jars on each date, containing 30 to $50 \mathrm{ml}$ of food suspension, depending upon the amounts of phytoplankton culture available on a given date. A control jar with no copepods was treated in the same manner as the experimental jars, and an initial sample of food suspension was preserved at the beginning of each experiment. Experimental jars were filled and sealed, without air bubbles inside, and mounted on a rotating wheel $(0.5 \mathrm{rpm})$, in a controlledtemperature room at $20.5^{\circ} \mathrm{C}$, on a $12: 12 \mathrm{~h} \mathrm{~L}$ :D cycle for $24 \mathrm{~h}$. We anticipated that performing grazing experiments partially in the light would allow the phytoplankton in the food suspensions to grow, possibly adding more cells to the food suspensions than were being removed by grazing and resulting in zero calculated grazing using Frost's (1972) equations. However, we performed experiments in this way so that the experimental conditions during the grazing experiments would be comparable to those during concurrent as well as previous egg-production and egg-hatching experiments conducted on a 12:12 h L:D cycle.

Food suspensions were prepared daily by first counting phytoplankton abundance in the stock cultures to be used as food, and then adjusting concentrations for use in the experimental food suspensions by dilution with filtered seawater, aiming at a final culture concentration in the experimental jars of approximately $10^{3}$ cells $\mathrm{ml}^{-1}$ of either THA or PRO for the 
unialgal, MIX and SWITCH experiments. Suspensions for the MIX diet were prepared after making up calculated dilutions and mixing thoroughly before pouring into the experimental containers to ensure homogenized cell suspensions. Since the total cell concentrations in the food suspensions were in excess compared to natural phytoplankton concentrations (except during blooms), it was assumed that copepods were able to feed ad libidum and that their grazing rates would not be limited by inadequate food concentrations. All cell counts and ingestion rates were later converted to carbon equivalents in order to normalize data.

Each morning of each $10 \mathrm{~d}$ experiment, copepods were removed from the experimental jars by gently pouring them into bowls, and were then re-pipetted into freshly prepared food suspensions. Any dead copepods were replaced with fresh individuals from the reserve treatments. After removal of copepods from food suspensions, these suspensions were preserved with Lugol's solution, and phytoplankton cell numbers were counted in Sedgwick-Rafter cells. At least 400 cells of THA and PRO were counted in all cases, ensuring $\pm 10 \%$ precision (Guillard 1973). Ingestion rates were determined from differences in phytoplankton cell concentrations in initial, control and triplicate experimental suspensions using the formulae of Frost (1972). Grazing rates for dead copepods were calculated assuming that they had fed for half of the experiment.

Egg production and hatching experiments. Experiments were also performed to determine daily egg production and hatching success for Temora stylifera couples fed (1) unialgal cultures of THA or PRO, and (2) mixtures of the 2 algae (MIX experiments), or (3) where one or the other food was provided on alternate days (SWITCH experiments). After dilution, microscopic counts of cells were made to confirm that THA and PRO were present in approximately equal proportions; if not, concentrations were adjusted and recounted until equal proportions were obtained. In a first set of experiments, 7 groups of 3 female and male couples were sorted into glass jars containing $300 \mathrm{ml}$ of ambient bay water. Couples were used in these experiments instead of females alone, and spermatophore production was measured to ensure that reduced egg viability was not due to absence of remating. Jars were mounted onto a rotating wheel $(0.5 \mathrm{rpm})$ in a controlled-temperature room at $20^{\circ} \mathrm{C}$ (the ambient temperature in the Gulf of Naples at the time of sampling) on a 12:12 h L:D cycle. After $24 \mathrm{~h}$, couples were transferred to new jars containing $300 \mathrm{ml}$ of $0.45 \mu \mathrm{m}$-filtered seawater, enriched with algal cultures, to a final concentration of $10^{3}$ cells ml-1. The contents of the jars were then poured into crystallizing dishes and allowed to settle to the container bottoms to determine initial in situ egg production, and numbers of fecal pellets.
Discarded spermatophores were counted under an inverted microscope. Hatching success was determined $48 \mathrm{~h}$ later by adding 95\% ethyl alcohol and counting the number of hatched nauplii after they had settled to the container bottoms. Each day, couples were transferred to new jars with fresh food suspensions and a daily record was kept of egg production, egg viability, crumpled egg membranes (representing cannibalized eggs: see Ianora et al. 1995), numbers of fecal pellets and spermatophores. The experimental period for all egg production/viability experiments was $20 \mathrm{~d}$, except for couples fed THA which were kept for only $15 \mathrm{~d}$ since eggs were not viable after this period and easily destroyed when bottle contents were poured into crystallizing dishes. Individuals were not replaced when they died, so that the final number of couples after the 15 or $20 \mathrm{~d}$ incubation period varied from 15 to 20 couples, highest mortality occuring with the THA diet (see Table 1).

Rotating bottles were employed to allow comparability of experimental conditions in grazing and egg-production/hatching experiments, since rotating bottles are conventionally used in copepod grazing experiments to prevent sedimentation of phytoplankton, particularly diatoms.

Egg-production values using the rotating jar experimental setup were considerably lower than those obtained in a previous study testing the same algal species with single copepod couples in crystallizing dishes containing $100 \mathrm{ml}$ suspensions (Ianora \& Poulet 1993). We therefore conducted a new series of experiments with 18 to 20 Temora stylifera female and male couples incubated as individual pairs in crystallizing dishes containing $100 \mathrm{ml}$ of ambient bay water. After $24 \mathrm{~h}$, couples were transferred to new containers with $100 \mathrm{ml}$ of $0.45 \mu \mathrm{m}$-filtered seawater enriched with algal cultures to a final concentration of $10^{3}$ cells ml-1 , and initial egg production and egg viability were determined. Thereafter, couples were transferred each day to new containers with fresh media and a tally was kept of daily egg production, egg viability, crumpled egg membranes, fecal pellets and spermatophores. In this case, all experiments were run for $20 \mathrm{~d}$ except for couples fed THA. The latter were kept for only $18 \mathrm{~d}$ since they produced only non-viable eggs thereafter. As for the rotating bottle experiments, hatching success was determined $48 \mathrm{~h}$ after spawning by adding $95 \%$ ethyl alcohol to containers and counting the number of hatched nauplii once they had settled to container bottoms.

Cannibalized eggs were counted in both crystallizing dish and rotating bottle experiments. For calculation of total egg production, the total numbers of eggs plus the total numbers of crumpled membranes were summed. For calculations of egg-hatching success, the numbers of 

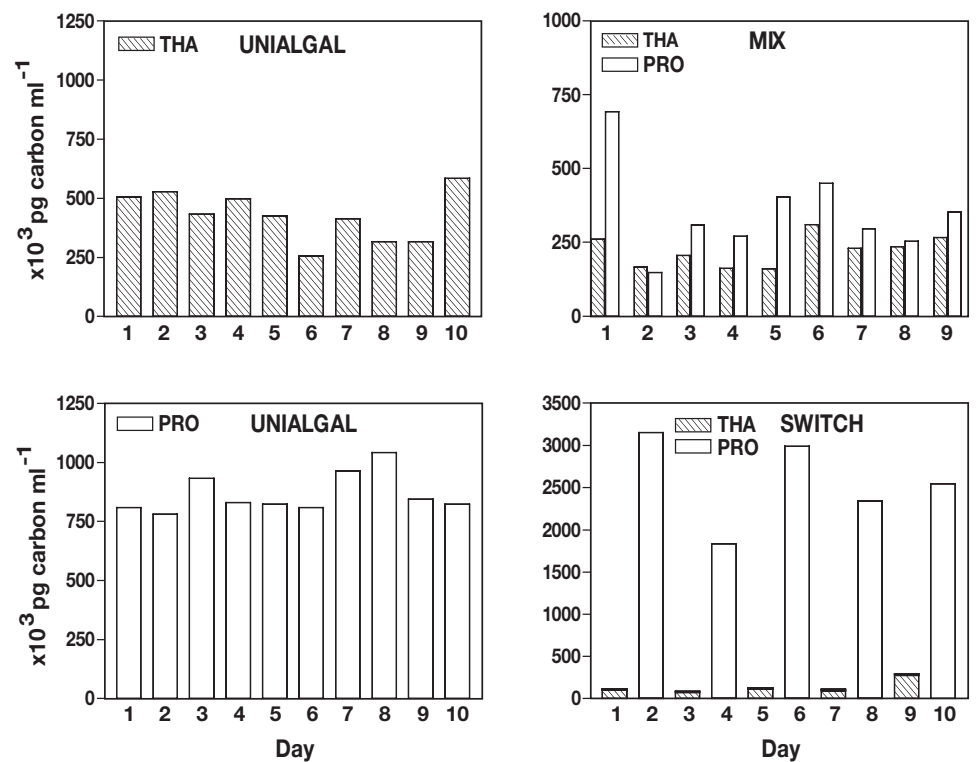

Fig. 1. Carbon content of the diatom Thalassiosira rotula (THA) and the dinoflagellate Prorocentrum minimum (PRO) offered to the copepod Temora stylifera as unialgal diets or as mixed foods for 10 consecutive days. In the mixed food experiments, both algae were either offered together on the same day (MIX) or one or the other algae was offered on alternate days (SWITCH)

hatched nauplii were compared to the numbers of eggs, not including crumpled membranes (see Ianora et al. 1995). Since in previous studies egg cannibalism in crystallizing dishes was low (Ianora et al. 1996, 1999b), in the present study we did not use screens in the bottoms of either type of experimental containers to separate copepods from their eggs, because we wanted to avoid damage to eggs by possible scraping as they sank through meshes; this might have prevented the hatching of otherwise viable eggs.

Statistical variations among treatments were tested with 1-way analysis of variance (ANOVA). When ANOVA indicated significant differences among treatments, multiple comparisons were made using Fisher's protected least-significant difference (PLSD) method.

\section{RESULTS}

Temora stylifera survival during the feeding experiments was good, even over the whole course of each 9 to $10 \mathrm{~d}$ study. In the SWITCH experiments, 9 of the total of 150 copepods died (6\%), and in the MIX experiments 4 of 135 copepods died (3\%). This is, to our knowledge, the first time that the same copepods have been used in sequential grazing experiments over 9 to $10 \mathrm{~d}$ periods.
Copepods ingested both THA and PRO, with the relative ingestion of each phytoplankter being generally stable on a day-today basis. Although the PRO diet usually contained more carbon (Fig. 1), the relative ingestion rates of THA and PRO were similar (Figs $2 \& 3$ ), and an analysis of variance calculated with 1-way ANOVA indicated that there was no significant difference $(F$-ratio $=$ 1.24; $\mathrm{df}=42 ; \mathrm{p}=0.05$ ) in the ingestion rates of THA and PRO among the different treatments

In the SWITCH experiments, the ingestion rates of THA and PRO were not consistently different during the first $5 \mathrm{~d}$, but on Days 6 and 8 there was no measurable ingestion of PRO, and on Day 9 there was no measurable ingestion of THA (Fig. 2). The lack of measured ingestion on these days was supported by the fact that there were almost no fecal pellets in the experimental food suspensions at the end of these experiments. The same also occurred for PRO on Day 6 in the mix experiments and on Day 7 in the unialgal PRO experiments (Fig. 2). On the other hand, copepods ingested very high quantities of PRO (in terms of carbon) on Day 1 in the unialgal PRO and MIX experiments and on Day 10 in the SWITCH experiments, indicating that this alga was willingly fed upon. Scanning electron microscope analyses of
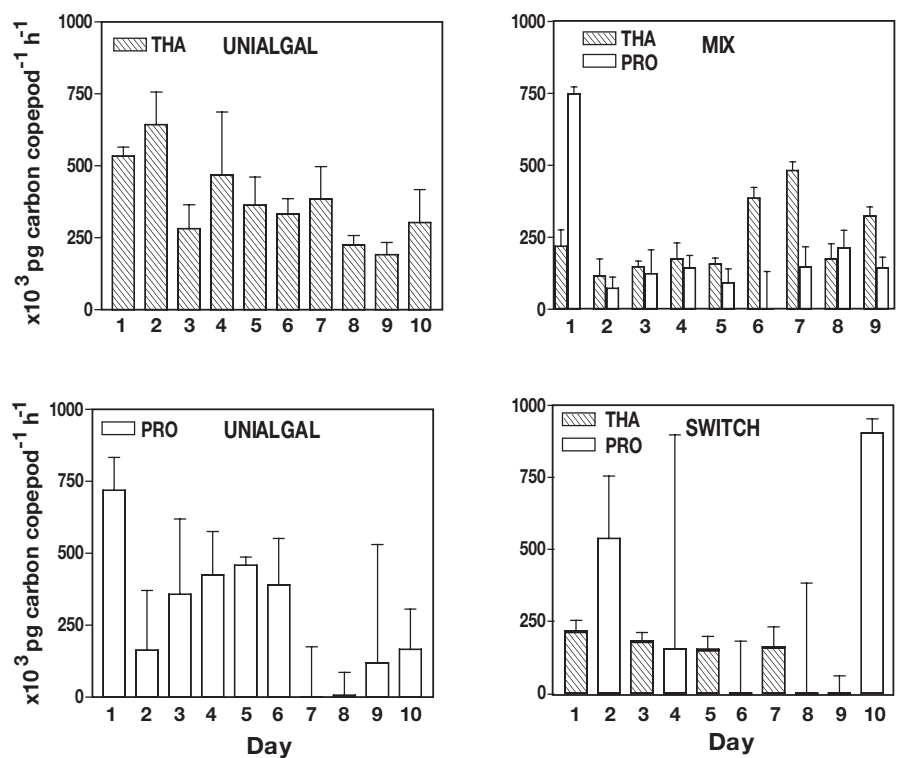

Fig. 2. Temora stylifera. Ingestion rates of copepods offered unialgal cultures of the diatom Thalassiosira rotula (THA) or the dinoflagellate Prorocentrum minimum (PRO), or both algae together on the same day (MIX), or when one or the other alga on alternate days (SWITCH). Datapoints are means of 3 replicates ( $\pm 1 \mathrm{SD}$ ) 


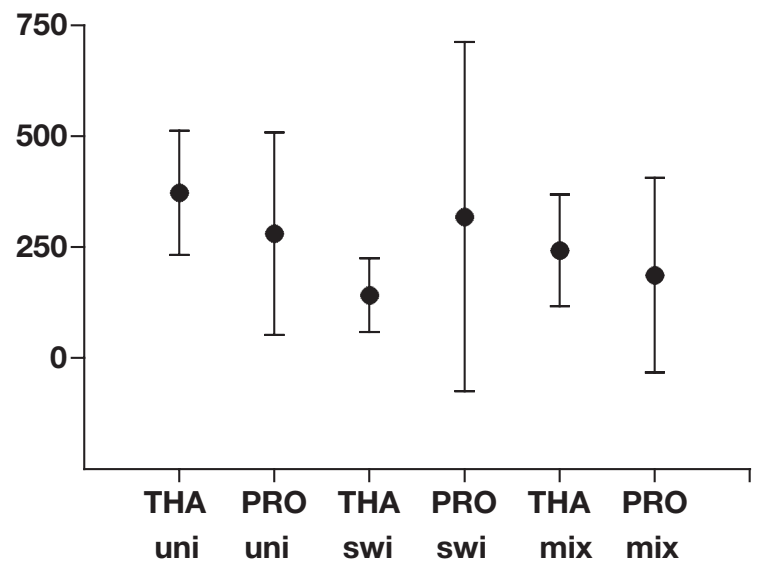

Fig. 3. Temora stylifera. Overall mean $( \pm 1 \mathrm{SD})$ ingestion rates of females offered unialgal cultures of the diatom Thalassiosira rotula (THA uni) or the dinoflagellate Prorocentrum minimum (PRO uni), or one or the other alga on alternate days (THA swi, PRO swi), or both algae together on the same day (THA mix, PRO mix). $\mathrm{n}$ (daily means of 3 replicates each) for each type of food $=10$ for unialgal, 5 for SWITCH, and 9 for MIX experiments (see Fig. 2)

fecal pellets produced during the MIX experiments confirmed that both phytoplankters were being ingested.

Higher egg-production rates were generally obtained when females were incubated in crystallizing dishes, whatever the diet (Figs 4 \& 5). Egg production rates for females fed THA, MIX or SWITCH diets were higher (F-test, p <0.05) than those of females fed PRO, whatever the incubation method (Table 1). The highest absolute egg-production rates were obtained for couples fed MIX diets and incubated in crystallizing dishes; their mean rates were double $(72.15 \pm 18.6 \mathrm{SD}$ eggs female $\mathrm{e}^{-1} \mathrm{~d}^{-1}$ ) those obtained with any other diet or any other incubation method (Table 1). Conversely, lowest absolute egg-production rates were obtained for couples fed PRO and maintained in rotating bottles (Table 1). Generally, egg-production rates diminished as a function of time in almost all treatments (Figs 4 \& 5).

Egg cannibalism was lower in crystallizing dishes $(4.5 \% \pm 4.2 \mathrm{SD})$ than in rotating bottles $(16.1 \% \pm 14.2 \mathrm{SD})$.

Egg viability was greatly influenced by food type (Figs 4 \& 5). It was initially high with all diets (>80\%) but decreased sharply with the THA diet, reaching $0 \%$ hatching within 15 and $17 \mathrm{~d}$ in rotating bottles and crystallizing dishes, respectively. THA inhibited egghatching success when it was the only food and when it occurred in MIX and SWITCH diets (1-way ANOVA, $F$-ratio $=40.79, \mathrm{df}=7, \mathrm{p}<0.05)$. The diminution in hatching success was less precipitous when females were fed MIX or SWITCH diets. In most cases, hatching success diminished to $<25 \%$ by the end of the incubation period, but in the case of couples incubated in crystallizing dishes with the SWITCH diet, hatching diminished to $0 \%$ after $16 \mathrm{~d}$ of feeding. Egg viability did not decrease as rapidly in the rotating bottles as in

Table 1. Temora stylifera. Variations in mean egg production female $\mathrm{d}^{-1}, \%$ egg viability, fecal pellets couple $\mathrm{d}^{-1}$, and spermatophores male ${ }^{-1} \mathrm{~d}^{-1}$ of copepods fed unialgal diets of the dinoflagellate Prorocentrum minimum (PRO) or the diatom Thalassiosira rotula (THA), a mixture of the 2 species (MIX) or one or the other species on alternate days (SWITCH). Diets with the same letter (A, B, C, D) are not significantly different (Fisher's PLSD, p > 0.05); those with no letter are significantly different from the other diets ( ${ }^{*}$ significant at $\left.95 \%\right)$

\begin{tabular}{|c|c|c|c|c|c|c|c|c|c|c|}
\hline \multirow{2}{*}{$\begin{array}{l}\text { Biological } \\
\text { response }\end{array}$} & \multicolumn{4}{|c|}{ Crystallizing dish experiments } & \multicolumn{4}{|c|}{ Rotating bottle experiments } & \multirow[t]{2}{*}{ df } & \multirow{2}{*}{$\begin{array}{c}\text { F-ratio } \\
\text { (1-way } \\
\text { ANOVA) }\end{array}$} \\
\hline & $\begin{array}{c}\text { PRO } \\
(\mathrm{n}=20)\end{array}$ & $\begin{array}{l}\text { THA } \\
(\mathrm{n}=18)\end{array}$ & $\begin{array}{c}\text { MIX } \\
(\mathrm{n}=20)\end{array}$ & $\begin{array}{l}\text { SWITCH } \\
(\mathrm{n}=20)\end{array}$ & $\begin{array}{c}\text { PRO } \\
(\mathrm{n}=20)\end{array}$ & $\begin{array}{c}\text { THA } \\
(\mathrm{n}=15)\end{array}$ & $\begin{array}{l}\text { MIX } \\
(\mathrm{n}=20)\end{array}$ & $\begin{array}{r}\text { SWITCH } \\
(\mathrm{n}=20)\end{array}$ & & \\
\hline $\begin{array}{l}\text { Eggs } \\
\text { female }^{-1} \mathrm{~d}^{-1}\end{array}$ & $\begin{array}{l}18.36 \\
\text { (SD: } 7.65) \\
\text { A }\end{array}$ & $\begin{array}{l}37.28 \\
\text { (SD: 16.81) } \\
\text { B }\end{array}$ & $\begin{array}{l}72.15 \\
\text { (SD: 18.65) }\end{array}$ & $\begin{array}{l}29.33 \\
\text { (SD: 16.26) } \\
\text { B,C,D }\end{array}$ & $\begin{array}{c}6.05 \\
\text { (SD: 10.28) }\end{array}$ & $\begin{array}{c}31.77 \\
\text { (SD: 19.79) } \\
\text { B,D }\end{array}$ & $\begin{array}{l}22.11 \\
(\mathrm{SD}: 8.36) \\
\mathrm{A}, \mathrm{C}\end{array}$ & $\begin{array}{c}21.8 \\
(\mathrm{SD}: 7.66) \\
\mathrm{A}, \mathrm{C}\end{array}$ & 7 & $40.79^{*}$ \\
\hline $\begin{array}{l}\% \text { egg } \\
\text { viability }\end{array}$ & $\begin{array}{l}87.65 \\
(\mathrm{SD}: 9.45)( \\
\quad \mathrm{A}\end{array}$ & $\begin{array}{c}19.28 \\
\text { (SD: } 8.26)\end{array}$ & $\begin{array}{l}49.29 \\
(\mathrm{SD}: 16.44) \\
\quad \mathrm{C}\end{array}$ & $\begin{array}{l}49.87 \\
\text { (SD: } 22.31) \\
\quad \text { C }\end{array}$ & $\begin{array}{c}96.53 \\
(\mathrm{SD}: 6.53) \\
\mathrm{A}\end{array}$ & $\begin{array}{c}39.96 \\
\text { (SD: } 27.36) \\
\text { C }\end{array}$ & $\begin{array}{l}66.67 \\
\text { (SD: 28.13) } \\
\text { B }\end{array}$ & $\begin{array}{l}71.71 \\
\text { (SD: } 17.28) \\
\text { B }\end{array}$ & 7 & $32.84^{*}$ \\
\hline $\begin{array}{l}\text { Fecal pellets } \\
\text { couple }^{-1} \mathrm{~d}^{-1}\end{array}$ & $\begin{array}{l}\text { S } 36.92 \\
\text { (SD: 9.93) } \\
\text { A }\end{array}$ & $\begin{array}{l}48.62 \\
\text { (SD: } 16.46 \\
\quad \text { A }\end{array}$ & $\begin{array}{l}79.51 \\
\text { 6) (SD: 21.56) } \\
\quad \text { B }\end{array}$ & $\begin{array}{l}41.29 \\
\text { (SD: 24.89) } \\
\mathrm{A}\end{array}$ & $\begin{array}{c}17.81 \\
\text { (SD: 16.89) }\end{array}$ & $\begin{array}{c}132.79 \\
\text { (SD: 29.16) }\end{array}$ & $\begin{array}{l}79.18 \\
\text { (SD: 23.89) } \\
\quad \text { B }\end{array}$ & $\begin{array}{l}84.31 \\
\text { (SD: } 46.02) \\
\text { B }\end{array}$ & 7 & $32.32^{*}$ \\
\hline $\begin{array}{l}\text { Spermato- } \\
\text { phores } \\
\text { male }^{-1} d^{-1}\end{array}$ & $\begin{array}{c}0.14 \\
\text { (SD: } 0.08) \\
\text { A,B }\end{array}$ & $\begin{array}{c}0.21 \\
(\mathrm{SD}: 0.2) \\
\mathrm{A}, \mathrm{B}\end{array}$ & $\begin{array}{c}0.61 \\
\text { (SD: } 0.23) \\
\text { C }\end{array}$ & $\begin{array}{l}0.68 \\
\text { (SD: } 0.76) \\
\text { C }\end{array}$ & $\begin{array}{c}0.04 \\
\text { (SD: } 0.08) \\
\text { B }\end{array}$ & $\begin{array}{c}0.28 \\
\text { (SD: } 0.17) \\
\text { A,C,D }\end{array}$ & $\begin{array}{l}0.48 \\
\text { (SD: } 0.24) \\
\text { C,D }\end{array}$ & $\begin{array}{l}0.24 \\
(\mathrm{SD}: 0.2) \\
\mathrm{A}\end{array}$ & 7 & $9.86^{*}$ \\
\hline
\end{tabular}



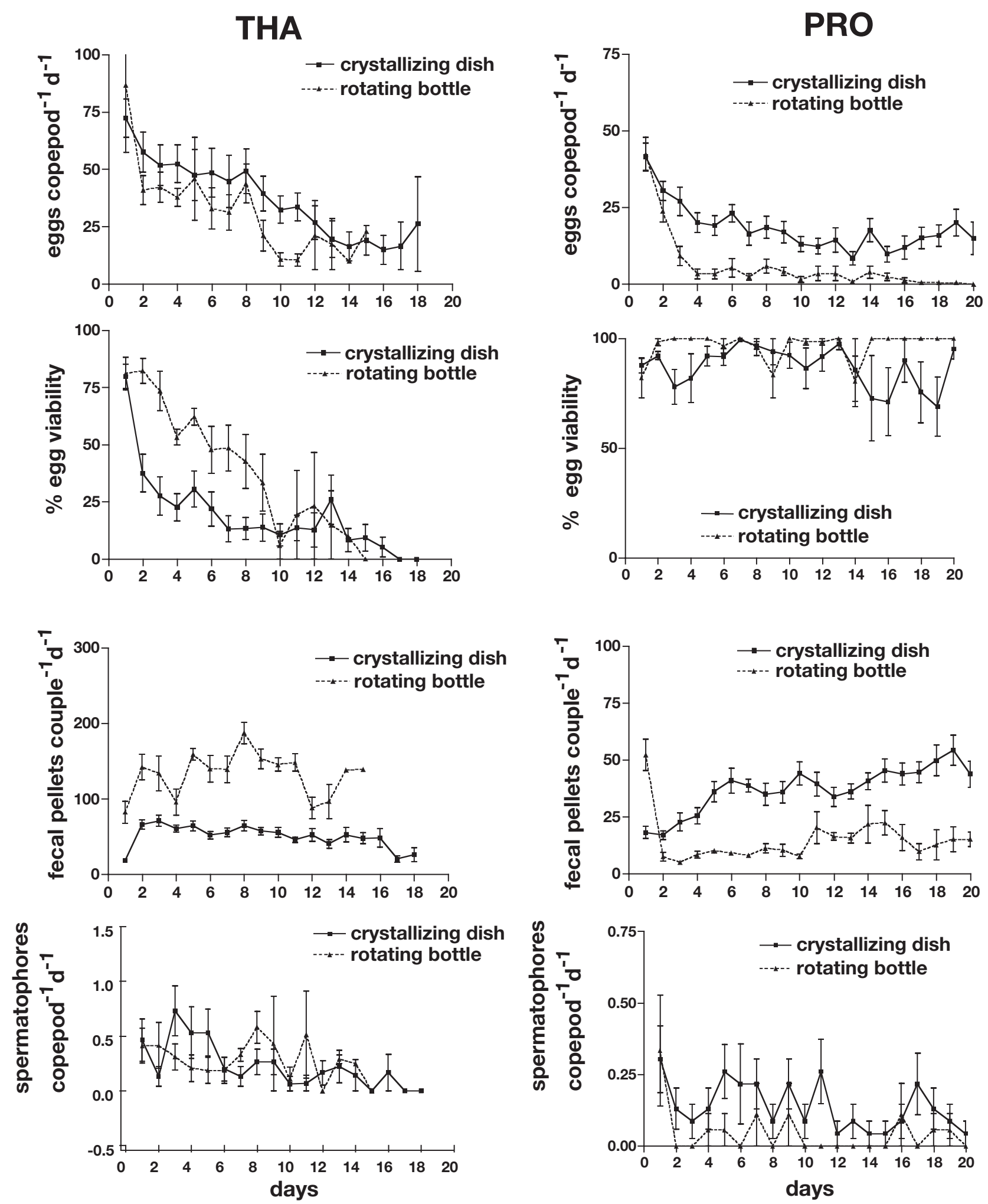

Fig. 4: Temora stylifera. Effect of 2 unialgal diets, the diatom Thalassiosira rotula (THA) and the dinoflagellate Prorocentrum minimum (PRO), on daily rates of egg production, \% egg viability, fecal pellet production and spermatophore production for copepod couples incubated either as individual pairs in $100 \mathrm{ml}$ crystallizing dishes or as triplicate pairs in $300 \mathrm{ml}$ rotating bottles. Data are means ( $\pm 1 \mathrm{SD}$ ) for numbers of replicates given in Table 1, namely 18 to 20 replicates for crystallizing dishes, and 15 to 20 repli- 


\section{MIX}
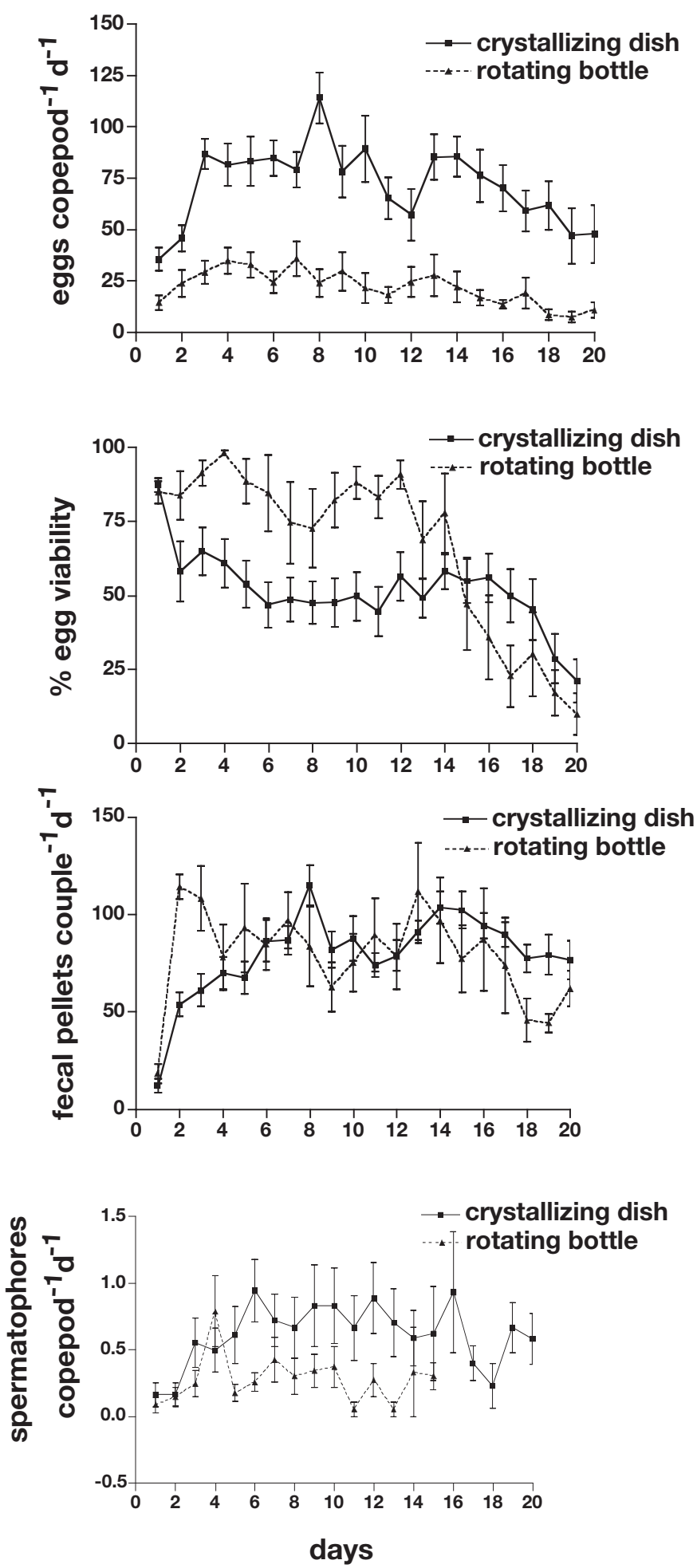

SWITCH
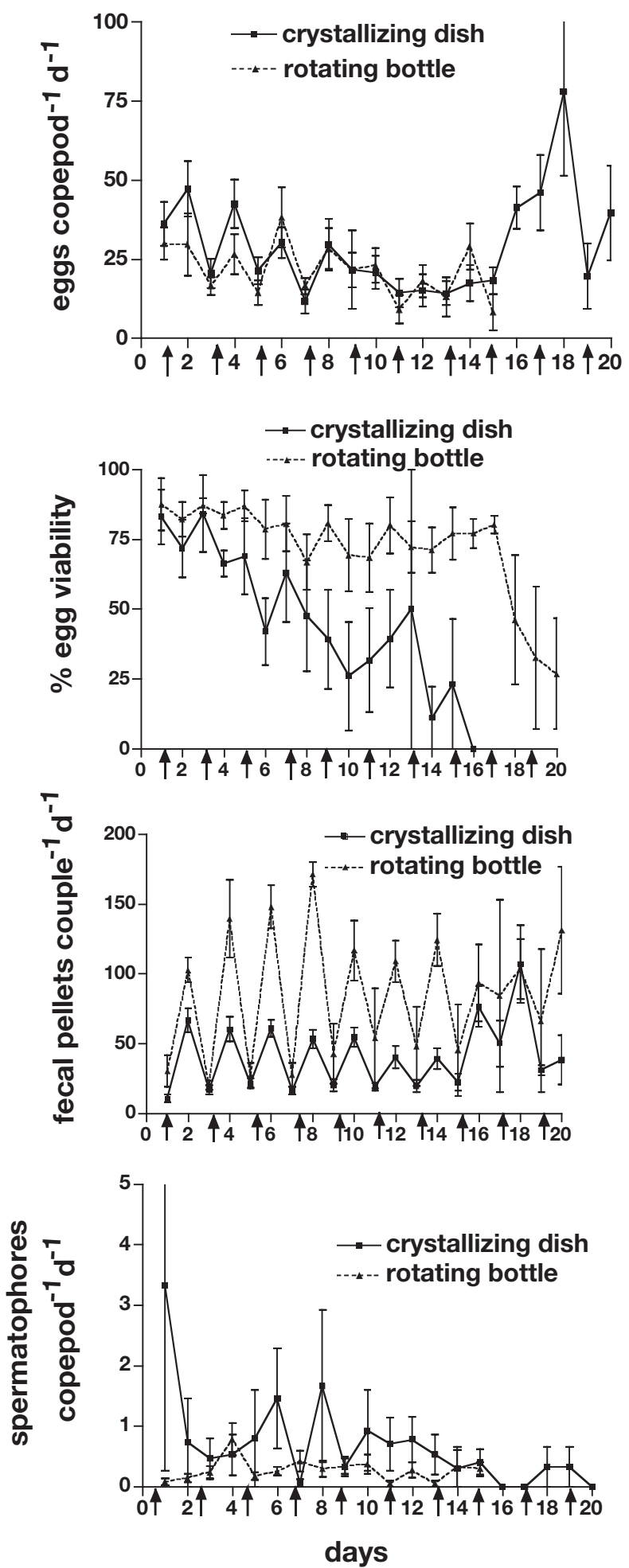

Fig. 5. Temora stylifera. Effect of 2 diets, the diatom Thalassiosira rotula and the dinoflagellate Prorocentrum minimum, when mixtures of both algae were offered together on the same day (MIX) or one or the other alga on alternating days (SWITCH) on daily egg production, \% egg viability, fecal pellet production and spermatophore production. Further details as in Fig. 4 

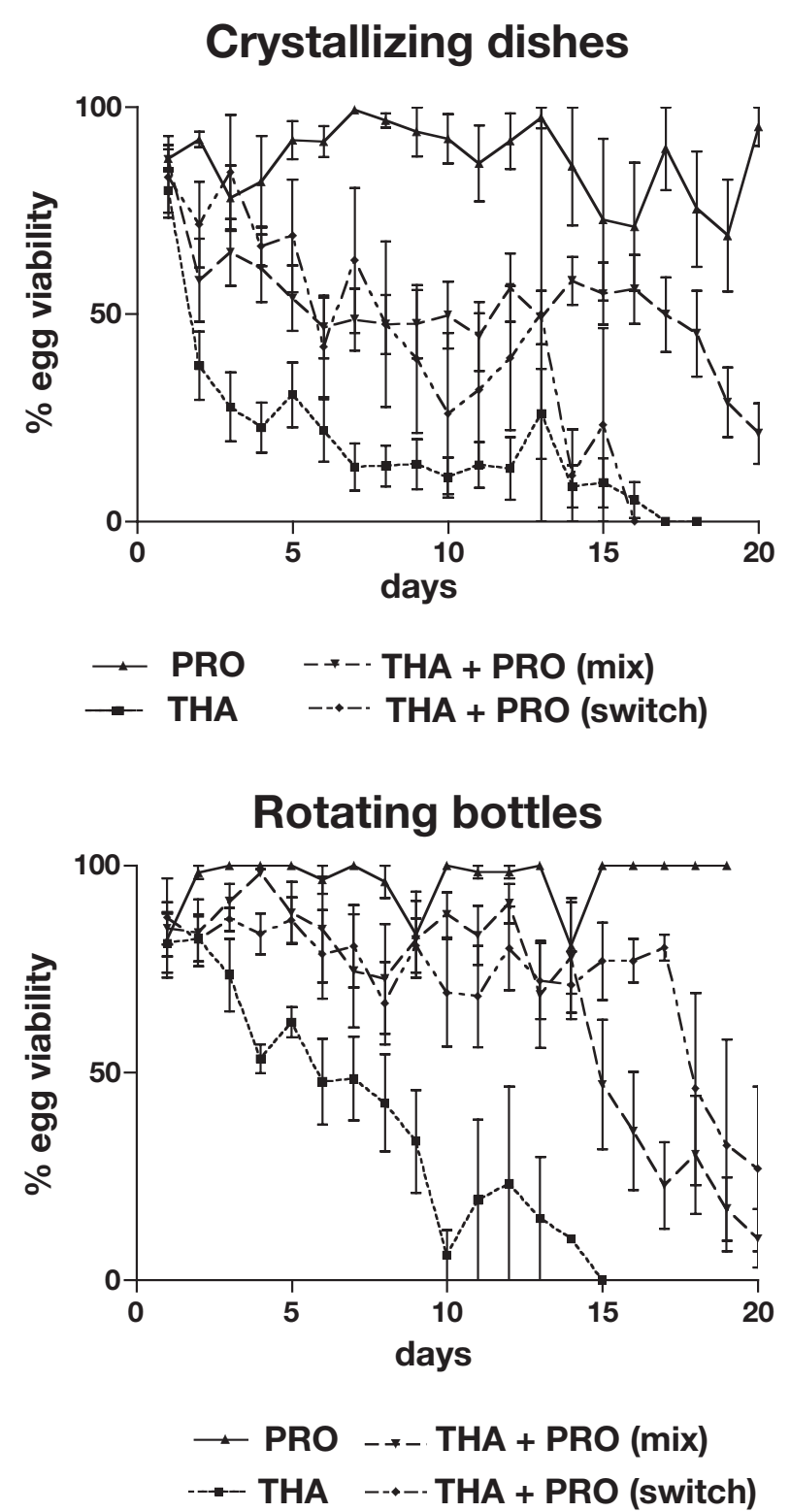

Fig. 6. Temora stylifera. Synopsis of daily variations in \% egg viability for copepod couples offered unialgal cultures of the dinoflagellate Prorocentrum minimum (PRO) or the diatom Thalassiosira rotula (THA), or both algae together on the same day (mix), or one or the other alga on alternate days (switch). Further details as in legend to Fig. 4

the crystallizing dishes, but even in the former, hatching diminished with time, especially during the second half of the incubation period (Fig. 5). Only in the case of the PRO diet was egg viability high and stable throughout (87 to $96 \%$ ), whatever the incubation condition (Table 1).

Fecal pellet production varied with time, depending on diet and the incubation method (Figs 4 \& 5). The highest $\left(132.79 \pm 29.1 \mathrm{SD}\right.$ pellets ind.$\left.^{-1} \mathrm{~d}^{-1}\right)$ and lowest $\left(17.81 \pm\right.$ 16.8 SD pellets ind.$\left.^{-1} \mathrm{~d}^{-1}\right)$ fecal pellet production rates were obtained when couples were fed THA or PRO, respectively, and incubated in rotating bottles (Table 1). Differences in fecal pellet production between diets were less marked for couples incubated in crystallizing dishes.

Spermatophore production was not significantly different ( F-test, p > 0.05) between THA and PRO diets, whatever the incubation method (Fig. 4, Table 1). However, males produced more spermatophores when incubated with MIX and SWITCH diets in crystallizing dishes (F-test, p < 0.05; Fig. 5, Table 1). The continuous production of spermatophores under all experimental conditions indicated that low egg-hatching success was not due to an absence of remating.

\section{DISCUSSION}

There was decoupling between diet and levels of feeding, fecundity, and egg viability in Temora stylifera in that diatom diets promoted high rates of feeding and egg production but low levels of egg-hatching success.

The relative ingestion rates of THA and PRO were similar in terms of carbon, and on a day-to-day basis the ingestion rates of both algae were relatively stable. There were somewhat larger fluctuations in the case of PRO, but the rates of ingestion of THA and PRO were similar even though copepods were offered more PRO in terms of carbon. Copepods may have been exhibiting size-selective feeding, ingesting more of the larger THA cells which occurred in chains rather than the smaller solitary PRO cells. In any case, this apparent preference for THA indicated that these cells did not contain any noxious compounds that deterred feeding by adult females.

Egg-production rates were much higher for diets containing THA than for PRO alone, despite similar rates of ingestion of THA and PRO. This suggests that THA was the better diet for promoting higher egg production. The addition of PRO in the mixed diets generally did not improve egg production rates except in the case of the crystallizing dish experiments, for which the highest absolute egg-production rates were obtained (Table 1).

Despite the fact that THA promoted higher egg production, it was deleterious to egg-hatching success whether THA was ingested alone or in combination in MIX and SWITCH diets. However, THA took longer to induce inhibition of egg-hatching in MIX and SWITCH diets than in unialgal THA diets, indicating dilution effects. Conversely, although PRO did not promote as high fecundity as THA, it provided the best egg hatching success. 

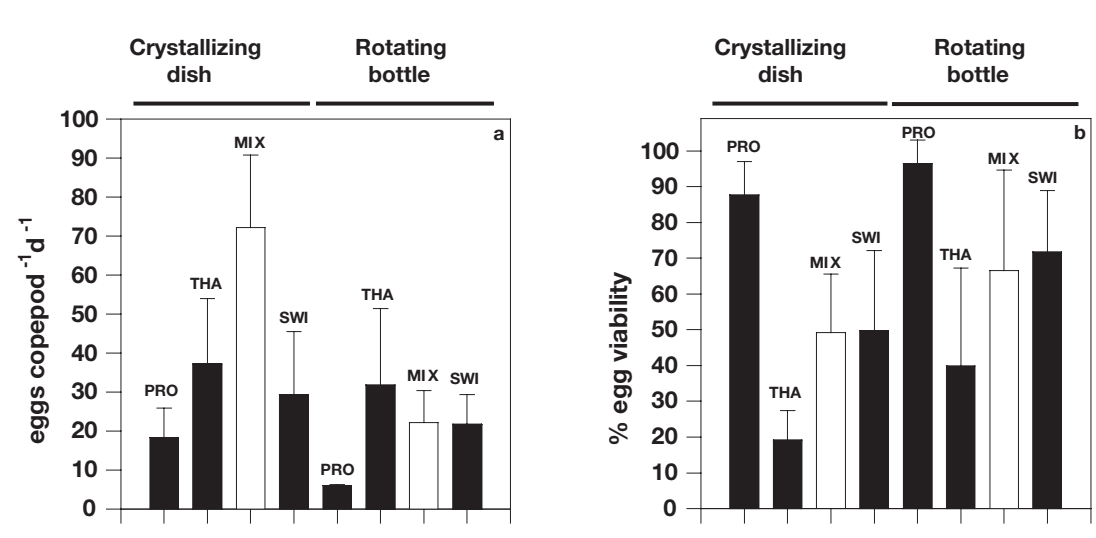

cess in both MIX and SWITCH experiments in crystallizing dishes and rotating bottles, respectively. Our result whereby egg-hatching success with mixed diets approached zero is similar to results of Lee et al. (1999) with the copepod Pseudocalanus newmani fed unialgal and mixed diets of the microflagellate Pavlova sp. and the diatom Chaetoceros gracilis. Lee et al. also found that egg viability in the diatom and mixed diets decreased with time, but hatching success in the mixed diets diminished less precipitously than in the present study.
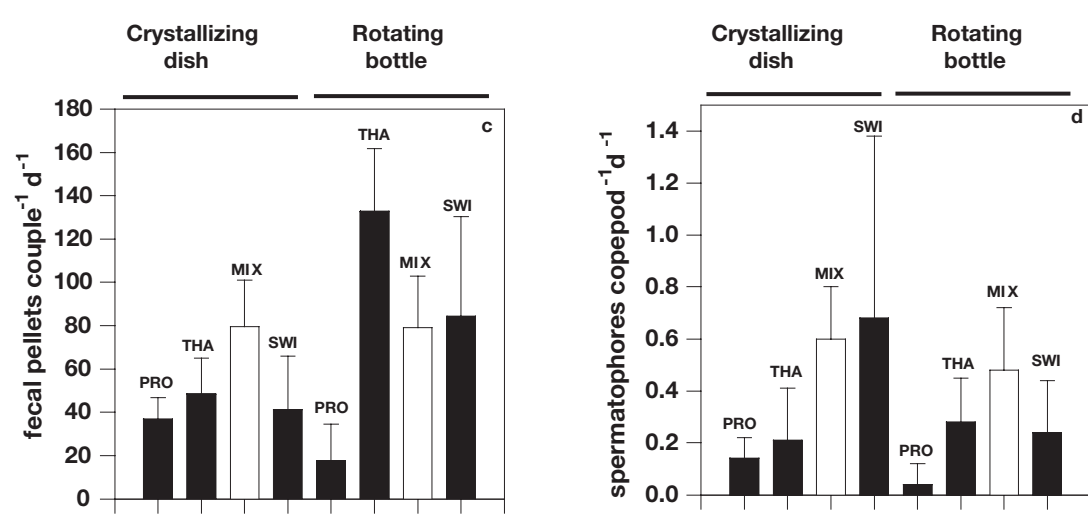

Fig. 7. Temora stylifera. Synopsis of differences in egg production, egg viability, fecal pellet production and spermatophore production among diets and between incubation methods for copepod couples offered unialgal cultures of the dinoflagellate Prorocentrum minimum (PRO) or the diatom Thalassiosira rotula (THA), or both algae together on the same day (MIX), or one or the other alga on alternate days (SWI). Further details as in legend Fig. 4

Another interesting aspect that emerges from these studies is the differences in rates of egg production, egg viability, cannibalized eggs and fecal pellet production in experiments performed in crystallizing dishes compared to those in rotating bottles (Fig. 7). Rates of egg production were generally higher in crystallizing dishes than in rotating bottles. Since 3 couples were in $300 \mathrm{ml}$ suspensions in rotating bottles whereas 1 couple was in $100 \mathrm{ml}$ in each crystallizing dish, perhaps crowding contributed to the reduction of egg production in the rotating bottles. Miralto et al. (1996) demonstrated that crowding can reduce egg production when as few as 3 females are incubated together, compared to females incubated alone.

Why was egg-hatching success on diets containing THA so low? The answer is probably the presence of aldehydes in THA that have recently been shown to block mitosis in copepod eggs, sea urchin embryos, and human colon cancer cells (Miralto et al. 1999). These aldehydes arrest cell proliferation and induce apoptosis (i.e. programmed cell death) in a dose-dependent manner. Such a dosedependent effect was also suggested by our experiments, in that when copepods were feeding upon combination diets of THA and PRO, copepod egg-hatching was reduced by approximately half, and this effect took about twice as long to induce (Fig. 6). These results strongly support the conclusion that low hatching success of copepod eggs produced on the diatom diets was due to a toxin rather than a nutritional deficiency, since if essential nutrients were lacking in one food item, they would probably have been supplied by the other food item. On the other hand, if a species is toxic, mixing it with another non-toxic species should dilute but not remove its toxic effect. In the present study, THA mixed with PRO induced 0 and $\leq 25 \%$ hatching suc-
In a similar study performed subsequent to ours, Kang \& Poulet (2000) compared grazing, egg production and egg viability for Calanus helgolandicus females fed upon unialgal and mixed diets of the diatom Coscinodiscus curvatulus and the dinoflagellate Gymnodinium sanguinium incubated together either in rotating bottles or static vials. Kang \& Poulet found that the copepods fed non-selectively on different diets, ingesting the most abundant food in most experiments. Both egg production and hatching success were significantly reduced by unialgal or mixed diets containing high proportions of diatoms. The adverse effects of diatom diets on egg hatching were diminished when maternal diets contained lower proportions of diatoms, and when egg cannibalism was $>20 \%$ of total egg production. Egg cannibalism was higher in rotating bottles, with mean values of $39.6 \%$ compared to $0.4 \%$ in static cultures. Kang \& Poulet suggested that the higher egg viability in the rotating bottles may have been due to higher cannibalism of 
eggs; this may have diluted the deleterious effects of the diatom food since eggs are nutritious. In our experiments, the higher egg viability in the rotating bottles may also reflect the fact that non-viable eggs are very fragile and would have been more easily destroyed when pouring the contents of the rotating bottles into the crystallizing dishes (Fig. 8).

The discovery that diatoms produce chemicals that inhibit reproduction by their principal predators poses interesting evolutionary questions. Occam's razor might suggest that the probable function of such compounds would be to deter grazers. However, such deterrence would target copepod populations instead of individuals (by reducing the reproductive success of future generations) rather than depressing feeding by immediate grazers such as adults feeding during the initial stages of blooms (Uye 1986). Since both phytoplankton blooms and copepod generations can occur over time scales of several weeks to a month, reduction of future grazing pressure by diminishing the size of successive generations of grazers might contribute to the persistence of phytoplankton blooms.

Diatom aldehydes such as those described by Miralto et al. (1999) may also be advantageous to the diatoms themselves, only incidentally reducing copepod reproductive success. Such advantages might include autoregulation of phytoplankton population dynamics by limiting excess population growth. For instance, the aldehydes from Thalassiosira rotula also seem to block cell division in this as well as other diatom species ( $R$. Casotti unpubl. data).

Adult copepods appear to be unaware of these antimitotic compounds, and thus eat these diatoms with impunity, even though they have deleterious effects on copepod reproduction. This is at variance with other phytoplankton toxins, some which can have direct antifeedant effects on copepods, but similar to some other phycotoxins which have no apparent effects (reviewed by Uye \& Takamatsu 1990, Turner \& Tester 1997, Turner et al. 1998). If diatom aldehydes evolved primarily in order to sabotage future generations of grazers, then this would be similar to many such chemical defenses evolved by terrestrial plants, which can act as abortive compounds for terrestrial grazers (Rosenthal \& Berenbaum 1991). The fact that copepods and some terrestrial animals have not evolved defenses to counteract the deleterious effects of such compounds could imply that evolutionary pressure may be stronger to detoxify direct antifeedant toxins than insidious cryptic ones which induce reproductive failure.

Acknowledgements. J.T.T. thanks the University of Massachusetts Dartmouth for a full-pay sabbatical during the fall, 1997 semester, and the Stazione Zoologica 'Anton Dohrn' for funding travel expenses. We appreciate the technical assis-

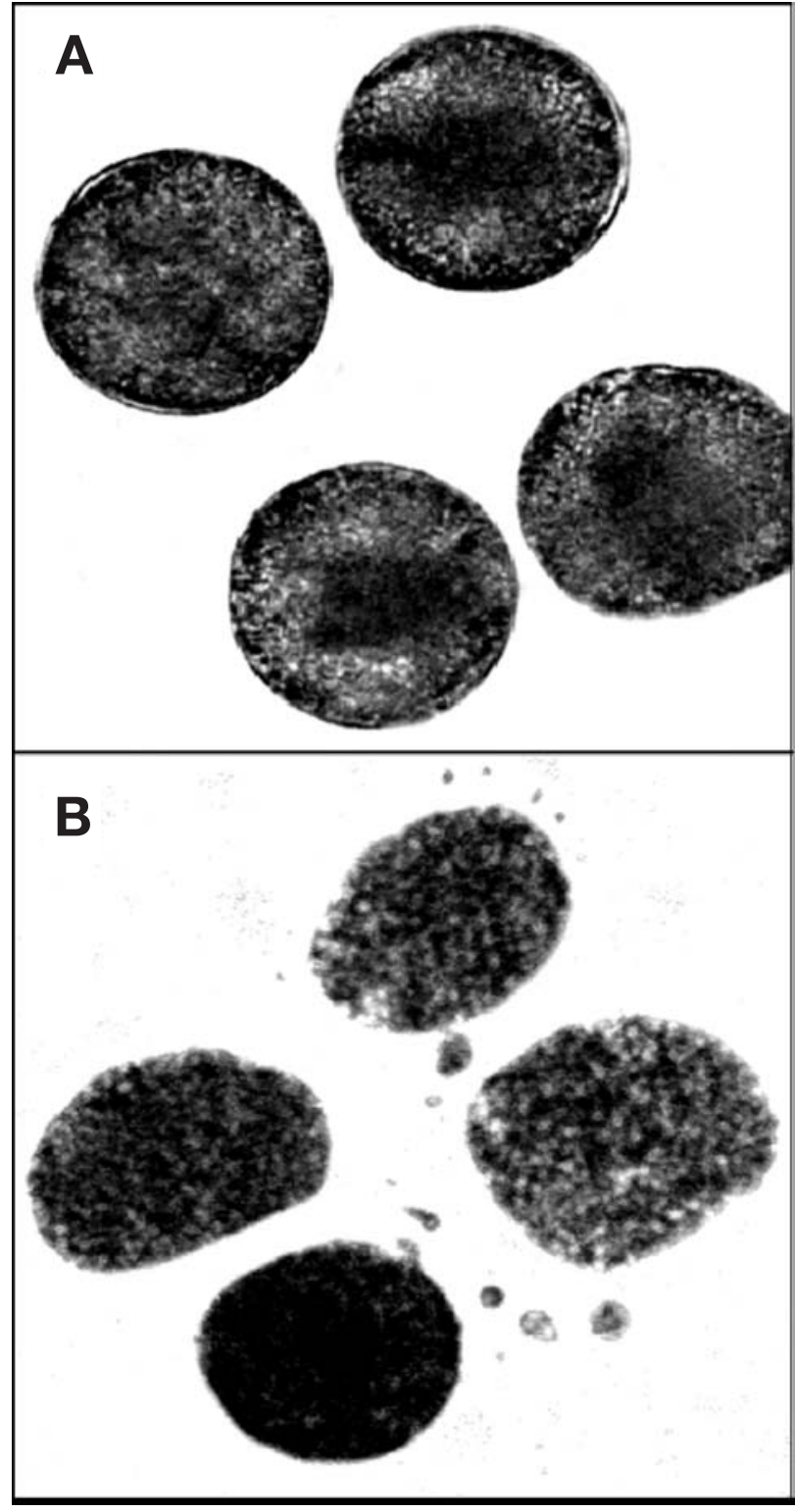

Fig. 8. Temora stylifera. Light micrograph images of eggs 5 min after spawning (A) and $24 \mathrm{~h}$ later (B) showing rapid disintegration of non-viable eggs

tance of Mario Di Pinto, and thank Russell Hopcroft for critical reading and help with computer graphics.

\section{LITERATURE CITED}

Ban S, Burns C, Castel J and 20 others (1997) The paradox of diatom-copepod interactions. Mar Ecol Prog Ser 157: 287-293

Cushing DH (1989) A difference in structure between ecosystems in strongly stratified waters and in those that are only weakly stratified. J Plankton Res 11:1-13

Dakin WJ (1908) Notes on the alimentary canal and food of the copepods. Int Rev Ges Hydrobiol Hydrogr 1:772-782

Frost BW (1972) Effects of size and concentration of food 
particles on the feeding behavior of the marine planktonic copepod Calanus pacificus. Limnol Oceanogr 17: 805-815

Guillard RRL (1973) Division rates. In: Stein JR (ed) Handbook of phycological methods. Cambridge University Press, Cambridge, p 289-311

Guisande C, Harris R (1995) Effect of total organic content of eggs on hatching success and naupliar survival in the copepod Calanus helgolandicus. Limnol Oceanogr 40: 476-482

Ianora A (1998) Copepod life history traits in subtemperate regions. J Mar Syst 15:337-349.

Ianora A, Poulet SA (1993) Egg viability in the copepod Temora stylifera. Limnol Oceanogr 38:1615-1626

Ianora A, Poulet SA, Miralto A (1995) A comparative study of the inhibitory effect of diatoms on the reproductive biology of the copepod Temora stylifera. Mar Biol 121: 533-539

Ianora A, Poulet SA, Miralto A, Grottoli R (1996) The diatom Thalassiosira rotula affects reproductive success in the copepod Acartia clausi. Mar Biol 125:279-286

Ianora A, Miralto A, Poulet SA (1999a) Are diatoms good or toxic for copepods? Reply to comment by Jónasdóttir et al. Mar Ecol Prog Ser 177:305-308

Ianora A, Miralto A, Buttino I, Romano G (1999b) First evidence of some dinoflagellates reducing male copepod fertilization capacity. Limnol Oceanogr 44:147-153

Irigoien X, Harris RP, Head RN, Harbour D (2000) The influence of diatom abundance on the egg production rate of Calanus helgolandicus in the English Channel. Limnol Oceanogr 45:1433-1439

Jónasdóttir SH (1994) Effects of food quality on the reproductive success of Acartia tonsa and Acartia hudsonica: laboratory observations. Mar Biol 121:67-81

Jónasdóttir SH, Kiørboe T (1996) Copepod recruitment and food composition: do diatoms affect hatching success? Mar Biol 125:743-750

Jónasdóttir SH, Fields D, Pantoja S (1995) Copepod egg production in Long Island Sound, USA, as a function of the chemical composition of seston. Mar Ecol Prog Ser 119: $87-98$

Jónasdóttir SH, Kiørboe T, Tang KW, St. John M, Visser AW, Saiz E, Dam HG (1998) Role of diatoms in copepod production: good, harmless or toxic? Mar Ecol Prog Ser 172: 305-308

Kang HK, Poulet SA (2000) Influence of single, mixed diets and egg cannibalism on the reproductive response of Calanus helgolandicus. Mar Ecol Prog Ser 201:241-250

Klein Breteler WCM, Schogt N, Baas M, Schouten S, Kraay GW (1999) Trophic upgrading of food quality by protozoans enhancing copepod growth: role of essential lipids. Mar Biol 135:191-198

Kleppel GS (1993) On the diets of calanoid copepods. Mar Ecol Prog 99:183-195

Kleppel GS, Holiday DV, Pieper RE (1991) Trophic interactions between copepods and microplankton: a question about the role of diatoms. Limnol Oceanogr 36:172-178

Koski M, Klein Breteler W, Schogt N (1998) Effect of food quality on rate of growth and development of the pelagic copepod Pseudocalanus elongatus (Copepoda, Calanoida). Mar Ecol Prog Ser 170:169-187

Koski M, Engström J, Viitasalo M (1999) Reproduction and survival of the calanoid copepod Eurytemora affinis fed with toxic and non-toxic cyanobacteria. Mar Ecol Prog Ser 186:187-197

Laabir M, Poulet SA, Ianora A, Miralto A, Cueff A (1995) Reproductive response of Calanus helgolandicus. II. In situ inhibition of embryonic development. Mar Ecol Prog Ser 129:97-105

Laabir M, Poulet SA, Harris RP, Pond DW, Cueff A, Head RN, Ianora A (1998) Comparative study of the reproduction of Calanus helgolandicus in well-mixed and seasonallystratified coastal waters of the western English Channel. J Plankton Res 20:407-421

Laabir M, Poulet SA, Cueff A, Ianora A (1999) Effect of diet on levels of amino acids during embryonic and naupliar development of the copepod Calanus helgolandicus. Mar Biol 134:89-98

Lee HW, Ban S, Ando Y, Ohta T, Ikeda T (1999) Deleterious effect of diatom diets on egg production and hatching success in the marine copepod Pseudocalanus newmani. Plankton Biol Ecol 46:104-112

Legendre L (1990) The significance of microalgal blooms for fisheries and for the export of particulate organic carbon in oceans. J Plankton Res 12:681-699

Marshall SM (1924) The food of Calanus finmarchicus during 1923. J Mar Biol Assoc UK 13:473-479

Marshall SM (1973.) Respiration and feeding in copepods. Adv Mar Biol 11:57-120

Mauchline J (1998) The biology of calanoid copepods. Adv Mar Biol 33: 1-710

Miralto A, Ianora A, Poulet SA, Romano G, Laabir M (1996) Is fecundity modified by crowding in the copepod Centropages typicus? J Plankton Res 18:1033-1040

Miralto A, Barone G, Romano G and 8 others (1999) The insidious effect of diatoms on copepod reproduction. Nature 402:173-176

Ohman MD, Runge JA (1994) Sustained fecundity when phytoplankton resources are in short supply: omnivory by Calanus finmarchicus in the Gulf of St. Lawrence. Limnol Oceanogr 39:21-36

Paffenhöfer GA, Harris RP (1979) Laboratory culture of marine holozooplankton and its contribution to studies of marine planktonic food webs. Adv Mar Biol 16:211-308

Pond D, Harris R, Head R, Harbour D (1996) Environmental and nutritional factors determining seasonal variability in the fecundity and egg viability of Calanus helgolandicus in coastal waters off Plymouth, UK. Mar Ecol Prog Ser 143: $45-63$

Poulet SA, Ianora A, Miralto A, Meijer L (1994) Do diatoms arrest embryonic development in copepods? Mar Ecol Prog Ser 111:79-86

Rosenthal GA, Berenbaum MR (1991) Herbivores: their interactions with sedondary plant metabolites, Vol 1 . The chemical participants. Academic Press, San Diego

Runge JA, de Lafontaine Y (1996) Characterization of a pelagic food web in the northern Gulf of St. Lawrence: the larval redfish-Calanus-microplankton interaction. Fish Oceanogr 5:21-37

Schmidt K, Jónasdóttir SH (1997) Nutritional quality of two cyanobacteria: how rich is 'poor' food? Mar Ecol Prog Ser 151:1-10

Starr M, Runge JA, Therrialt J-C (1999) Effects of diatom diets on the reproduction of the planktonic copepod Calanus finmarchicus. Sarsia 84:379-389

Turner JT (1984) The feeding ecology of some zooplankters that are important prey items of larval fish. NOAA Tech Rept NMFS 7:1-28

Turner JT (2000) Feeding ecology of marine copepods: an overview of recent studies and emerging issues. In: Hwang JS, Wang CH, Chan TY (eds) Proceedings of the International Symposium on Marine Biology in TaiwanCrustaceans and zooplankton: taxonomy, ecology and living resources, 26-27 May 1998, National Taiwan 
Museum, Taipei, Special Publication Series No. 10:37-57 Turner JT, Roff JC (1993) Trophic levels and trophospecies in marine plankton: lessons from the microbial food web. Mar Microb Food Webs 7:225-248

Turner JT, Tester PA (1997) Toxic marine phytoplankton, zooplankton grazers, and pelagic food webs. Limnol Oceanogr 42:1203-1214

Turner JT, Tester PA, Hansen PJ (1998) Interactions between toxic marine phytoplankton and metazoan and protistan grazers. In: Anderson DM, Cembella AD, Hallegraeff GM

Editorial responsibility: Otto Kinne (Editor), Oldendorf/Luhe, Germany (eds) Physiological ecology of harmful algal blooms, NATO ASI Series, Vol G 41. Springer-Verlag, Berlin, p 453-474 Uye SI (1986) Impact of copepod grazing on the red-tide flagellate Chattonella antiqua. Mar Biol 92:35-43

Uye SI (1996) Induction of reproductive failure in the planktonic copepod Calanus pacificus by diatoms. Mar Ecol Prog Ser 133:89-97

Uye SI, Takamatsu K (1990) Feeding interactions between planktonic copepods and red-tide flagellates from Japanese coastal waters. Mar Ecol Prog Ser 59:97-107

Submitted: August 30, 2000; Accepted: November 28, 2000 Proofs received from author(s): September 10, 2001 